University of Nebraska - Lincoln

DigitalCommons@University of Nebraska - Lincoln

USDA National Wildlife Research Center - Staff Publications
U.S. Department of Agriculture: Animal and Plant Health Inspection Service

$10-21-2003$

\title{
USING FECAL GLUCOCORTICOIDS FOR STRESS ASSESSMENT IN MOURNING DOVES
}

\author{
Brian E. Washburn \\ University of Missouri, Columbia, brian.e.washburn@aphis.usda.gov \\ Joshua J. Millspaugh \\ University of Missouri, Columbia, joshua.millspaugh@umontana.edu \\ John H. Schulz \\ Missouri Department of Conservation \\ Susan B. Jones \\ USGS Columbia Environmental Research Center \\ Tony Mong \\ University of Missouri, Columbia
}

Follow this and additional works at: https://digitalcommons.unl.edu/icwdm_usdanwrc

Part of the Environmental Sciences Commons

Washburn, Brian E.; Millspaugh, Joshua J.; H. Schulz, John; Jones, Susan B.; and Mong, Tony, "USING FECAL GLUCOCORTICOIDS FOR STRESS ASSESSMENT IN MOURNING DOVES" (2003). USDA National Wildlife Research Center - Staff Publications. 520.

https://digitalcommons.unl.edu/icwdm_usdanwrc/520

This Article is brought to you for free and open access by the U.S. Department of Agriculture: Animal and Plant Health Inspection Service at DigitalCommons@University of Nebraska - Lincoln. It has been accepted for inclusion in USDA National Wildlife Research Center - Staff Publications by an authorized administrator of DigitalCommons@University of Nebraska - Lincoln. 


\title{
USING FECAL GLUCOCORTICOIDS FOR STRESS ASSESSMENT IN MOURNING DOVES
}

\author{
Brian E. Washburn ${ }^{1,4}$, Joshua J. Millspaugh ${ }^{1}$, John H. Schulz ${ }^{2}$, \\ Susan B. JONES ${ }^{3}$ And TONy Mong ${ }^{1}$ \\ ${ }^{I}$ Department of Fisheries and Wildlife Sciences, University of Missouri, \\ 302 A-BNR Building, Columbia, MO 65211 \\ ${ }^{2}$ Missouri Department of Conservation, 1110 South College Avenue, Columbia, MO 65201 \\ ${ }^{3}$ USGS Columbia Environmental Research Center, 4200 New Haven Road, Columbia, MO 65201
}

\begin{abstract}
Fecal glucocorticoid assays provide a potentially useful, noninvasive means to study physiological responses of wildlife to various stressors. The objective of our study was to validate a method for measuring glucocorticoid metabolites in Mourning Dove (Zenaida macroura) feces. We validated the assay using standard procedures (e.g., parallelism, recovery of exogenous corticosterone) to demonstrate that the assay accurately and precisely measured glucocorticoid metabolites in Mourning Dove fecal extracts. We conducted adrenocorticotropin (ACTH) challenge experiments to validate the assay's ability to determine biologically important changes in fecal glucocorticoids. Fecal glucocorticoid levels increased significantly approximately $2-3 \mathrm{hr}$ after administration of ACTH at $50 \mathrm{IU}$ per kg body mass to wild Mourning Doves held in captivity. In contrast, fecal glucocorticoid metabolites did not increase in control birds, birds that received saline injections, or a lower dose of ACTH (1 IU per kg body mass). Variation in overall fecal glucocorticoid metabolite levels may have been influenced by season and the length of time birds were held in captivity. Noninvasive fecal glucocorticoid metabolite analyses, in combination with demographic information, may have considerable utility for monitoring the effects of natural and anthropogenic disturbances on Mourning Dove populations.
\end{abstract}

Key words: Columbiformes, corticosterone, feces, noninvasive, physiology, radioimmunoassay, stress.

\section{Uso de Glucocorticoides Fecales Para Evaluar el Estrés en Zenaida macroura}

Resumen. Las evaluaciones de glucocorticoides fecales representan un medio no invasor potencialmente útil para estudiar las respuestas fisiológicas de los animales silvestres ante agentes causantes de estrés. El objetivo de nuestro estudio fue validar un método para medir metabolitos glucocorticoides en heces de palomas Zenaida macroura. Validamos el método mediante procedimientos estándar (e.g., paralelismo, recuperación de corticosterona exógena) para demostrar que éste mide con exactitud y precisión los metabolitos glucocorticoides en extractos fecales de $Z$. macroura. Realizamos experimentos de desafío con adrenocorticotropina (ACTH) para validar la habilidad que tenía el método para determinar cambios biológicamente importantes en los glucocorticoides fecales. Los niveles de glucocorticoides fecales aumentaron de forma significativa aproximadamente $2-3 \mathrm{hr}$ después de la administración de ACTH a $50 \mathrm{IU}$ por $\mathrm{kg}$ de peso corporal a palomas silvestres mantenidas en cautiverio. En contraste, los metabolitos glucocorticoides fecales no aumentaron en aves control, ni en aves que recibieron inyecciones salinas o una menor dosis de ACTH (1 IU por $\mathrm{kg}$ de peso corporal). La variación en los niveles generales de metabolitos glucocorticoides fecales podría haber sido influenciada por la estación y la longitud del período de tiempo en que las aves fueron mantenidas en cautiverio. Los análisis no invasores de metabolitos glucocorticoides, en combinación con información demográfica, podrían ser de considerable utilidad para monitorear los efectos de los disturbios naturales y antropogénicos sobre las poblaciones de Z. macroura.

\footnotetext{
Manuscript received 15 October 2002; accepted 28 May 2003.

${ }^{4}$ Present address: USDA, Wildlife Services, National Wildlife Research Center, 6100 Columbus Avenue, Sandusky, OH 44870. E-mail: brian.e.washburn@aphis.usda.gov
} 


\section{INTRODUCTION}

Glucocorticoid release is the hallmark response to stressful stimuli in vertebrates (Holmes and Phillips 1976, Harvey et al. 1984). Elevations in glucocorticoids (primarily corticosterone in birds) allows animals to endure stressful periods (e.g., severe storms, Bray 1993, Wingfield et al. 1997) by initiating physiological and behavioral changes (e.g., energy mobilization, increased foraging). These acute stress responses can be beneficial by increasing short-term survival. However, chronic elevations in corticosterone may reduce an individual's fitness by immunosuppression and reproductive failure, leading to detrimental effects at various scales (e.g., individual to population levels; Wingfield et al. 1982, Dunlap and Schall 1985, Verme and Doepker 1988, Wingfield 1988).

Physiological stress in birds has traditionally been assessed by measuring plasma corticosterone levels (Wingfield et al. 1992, Holberton et al. 1996, Romero et al. 1997). However, activities related to capture and blood sampling can increase corticosterone levels and compromise meaningful stress assessment in relation to research objectives (Hamilton and Weeks 1985, Le Maho et al. 1992). Furthermore, long-term studies requiring repeated capture and blood collection may not be logistically possible in freeranging birds or may result in anemia in captive individuals (Clipsham 1991). Measurement of glucocorticoid metabolite concentrations in feces, however, may provide an alternative to blood collection for plasma corticosterone analysis in birds (Wasser et al. 2000, Ludders et al. 2001). Feces may be collected without capturing or disturbing the animal; thus longitudinal studies of focal individuals can be conducted noninvasively (Wasser et al. 2000). Such methods may be particularly useful in studies conducted on threatened or endangered species. Another benefit is that the stress of handling may not be reflected in the results, because it takes several hours for fecal glucocorticoid metabolites to be excreted in feces (Wasser et al. 2000, Millspaugh et al. 2001).

Noninvasive methods of stress assessment have proven reliable in a variety of animals (Wasser et al. 2000, Millspaugh et al. 2001, Ludders et al. 2001). However, the specific composition and proportion of fecal glucocorticoid metabolites varies among species; thus these non- invasive methods must be validated for each species prior to application (Wasser et al. 2000). Fecal glucocorticoid metabolite assays are validated for new species using a standard assay validation assessment (Grotjan and Keel 1996, O'Fegan 2000). In addition, a physiological validation is conducted to demonstrate the assay technique is capable of detecting biologically significant changes in fecal glucocorticoid levels (Wasser et al. 2000). A preferred method of physiologically validating these noninvasive methods is an adrenocorticotropic hormone $(\mathrm{ACTH})$ challenge. After a pretreatment period, the pituitary hormone ACTH is injected into the animal, causing an increase in the circulating levels of glucocorticoids (Romero and Wingfield 1999, 2001). Consequently an increase in glucocorticoid metabolites occurs in feces (Wasser et al. 2000, Ludders et al. 2001), but the timing of this change is delayed due to conjugation of glucocorticoids by the liver, their excretion in bile, and their passage through the gastrointestinal tract (Graham and Brown 1996, Bahr et al. 2000). By injecting ACTH and demonstrating that an increase in fecal glucocorticoid metabolites was detected by the assay procedure, the technique can be validated physiologically (Goymann et al. 1999, Wasser et al. 2000, Ludders et al. 2001, Millspaugh et al. 2002).

Fecal glucocorticoid metabolite assays have been validated for Northern Spotted Owls (Strix occidentalis caurina; Wasser et al. 1997), Florida Sandhill Cranes (Grus canadensis pratensis; Ludders et al. 2001), and Greylag Geese (Anser anser; Frigerio et al. 2001). This noninvasive method for monitoring adrenocortical activity may also be useful in birds of smaller body size, such as Mourning Doves. We selected Mourning Doves as a model species because they are an important upland gamebird, related information exists regarding their stress physiology (Schulz et al. 2001, Washburn et al. 2002), and wild Mourning Doves can be maintained easily in captivity (Mirarchi 1993a, Schulz et al. 2001). Our objectives were (1) to validate a radioimmunoassay (RIA) procedure to quantify fecal glucocorticoid metabolites in Mourning Dove feces and (2) to physiologically validate the technique's ability to detect biologically meaningful changes in fecal glucocorticoid metabolites in Mourning Doves. 
TABLE 1. Summary of fecal glucocorticoid experiments with Mourning Doves, including season, dates (in 2001), specific treatments, sample size and sex of birds, and length of captivity prior to the experiments.

\begin{tabular}{|c|c|c|c|}
\hline $\begin{array}{l}\text { Season } \\
\text { Date (2001) }\end{array}$ & Treatments $^{\mathrm{a}}$ & $n$ (male/female) & $\begin{array}{c}\text { Time in captivity } \\
\text { (months) }\end{array}$ \\
\hline \multicolumn{4}{|l|}{ Winter } \\
\hline 2-4 March & Saline & $0 / 1$ & 2.5 \\
\hline 2-4 March & ACTH (1 IU kg-1) & $0 / 1$ & 2.5 \\
\hline 25-27 March & Saline & $1 / 0$ & 3 \\
\hline 25-27 March & ACTH (1 IU kg-1) & $1 / 0$ & 3 \\
\hline \multicolumn{4}{|l|}{ Summer } \\
\hline 9-11 July & Control & $1 / 0$ & $4-6$ \\
\hline 9-11 July & Saline & $1 / 0$ & $4-6$ \\
\hline 9-11 July & ACTH (1 IU kg-1) & $0 / 1$ & $4-6$ \\
\hline 13-15 July & Control & $1 / 0$ & $4-6$ \\
\hline 13-15 July & Saline & $0 / 1$ & $4-6$ \\
\hline 13-15 July & ACTH (1 IU kg-1) & $1 / 0$ & $4-6$ \\
\hline \multicolumn{4}{|l|}{ Fall } \\
\hline 23-25 October & Control & $1 / 1$ & 5 \\
\hline 23-25 October & ACTH (50 IU kg-1) & $2 / 2$ & 5 \\
\hline
\end{tabular}

a ACTH dosages are given in International Units (IU) per $\mathrm{kg}$ of body mass.

\section{METHODS}

\section{STUDY ANIMALS}

We captured wild Mourning Doves using modified Kniffin traps (Reeves et al. 1968) baited with white proso millet near Columbia, Missouri $\left(38^{\circ} 54^{\prime} \mathrm{N}, 92^{\circ} 18^{\prime} \mathrm{W}\right)$ during several trapping periods from December 2000 to June 2001. All birds had reached the adult prebasic molt by the start of the experiments and were aged as afterhatch-year (AHY) birds. We maintained the Mourning Doves at the University of Missouri's T. S. Baskett Wildlife Research and Education Center, located near Ashland, Missouri $\left(38^{\circ} 45^{\prime} \mathrm{N}, 92^{\circ} 12^{\prime} \mathrm{W}\right)$. Mourning Doves were individually housed in $1.8 \times 1.8 \times 1.8 \mathrm{~m}$ outdoor cages. The outdoor cages were located under an open-sided, roofed building with a concrete floor. Thus, doves received protection from precipitation and direct sunlight but were exposed to daily fluctuations in air temperature and wind. A wild-bird seed mixture (sorghum grains, wheat, crimped corn, oats, and sunflower seed) and water were provided ad libitum.

\section{ACTH CHALLENGE EXPERIMENTS}

We conducted three sets of ACTH challenge experiments on wild Mourning Doves in captivity during 2 March 2001-25 October 2001 using a stratified random design (Table 1). During each challenge experiment, all fecal samples (feces plus urine) were collected for a $24-\mathrm{hr}$ pretreat- ment period, starting at 08:00 on day 1 of the experiment. Experimental treatments (e.g., ACTH injection) were given at 08:00 on day 2 . We collected all feces for $36 \mathrm{hr}$ post-treatment; experiments ended at 20:00 on day 3. We checked for fecal samples every hour and collected feces using a stainless steel spatula. Fecal samples were placed into 7-mL plastic vials and frozen at $-20^{\circ} \mathrm{C}$ within 10 min of collection.

During the initial experiments (winter), two male and two female Mourning Doves were randomly assigned to one of two treatments, stratified by sex: (1) saline ( $0.9 \%$ sodium chloride solution) or (2) ACTH (Cortrosyn ${ }^{\mathrm{TM}}$; Organon Inc., West Orange, New Jersey) at a total dose of 1 International Unit (IU) per kg body mass. For the purposes of comparison, we assumed that $0.01 \mathrm{mg}$ of Cortrosyn ${ }^{\mathrm{TM}}$ is the same as $1 \mathrm{IU}$ based on the manufacturer's product insert. This dose of ACTH was selected due to its effectiveness in increasing adrenocortical activity in other species (Wasser et al. 1997, 2000). Two separate injections (saline or 0.5 IU of ACTH per $\mathrm{kg}$ body mass) were given to extend the length of adrenocortical stimulation. On day 2, the first injection was given at 08:00 and the second at 08:30. The ACTH was given in a $0.9 \%$ sodium chloride vehicle solution. All injections for this and the subsequent two experiments were given intramuscularly into the pectoralis.

The second set of experiments, conducted in summer, consisted of four male and two female 
Mourning Doves randomly assigned to one of three treatment groups: (1) control (no handling or injection), (2) saline, or (3) ACTH at a total dose of $1 \mathrm{IU}$ per kg body mass. The timing and administration of treatments were the same as during the winter experiments.

Given our results from the first two sets of experiments (winter and summer), we conducted a third experiment to determine if a higher dose of ACTH was necessary to increase adrenocortical activity in Mourning Doves. During this experiment, we randomly assigned three males and three females to one of two treatments: (1) control or (2) ACTH at $50 \mathrm{IU}$ per kg body mass. During this experiment, the ACTH was administered using a single injection given at 08:00 on day 2 of the experiment.

\section{FECAL SAMPLE PREPARATION}

Frozen fecal samples were placed in a lyophilizer (Freeze-dry Specialties, Inc., Osseo, Minnesota) for $24 \mathrm{hr}$. Once freeze dried, samples were ground, sifted through a stainless steel mesh (No. 25 standard US units) to remove large particles, and thoroughly mixed. Glucocorticoid metabolites were extracted from feces using a modification of Schwarzenberger et al. (1991). Dried feces $(0.016$ to $0.125 \mathrm{~g})$ were placed in a test tube with $2.0 \mathrm{~mL}$ of $90 \%$ methanol and vortexed at high speed in a multitube vortexer for $30 \mathrm{~min}$. Samples were then centrifuged at $500 \mathrm{~g}$ for $20 \mathrm{~min}$, and the supernatant was saved and stored at $-84^{\circ} \mathrm{C}$.

\section{RADIOIMMUNOASSAY PROCEDURES AND ASSAY VALIDATION}

We measured fecal glucocorticoid metabolite levels in Mourning Dove fecal extracts using a commercially available corticosterone $\mathrm{I}^{125}$ radioimmunoassay kit (Cat. \#07-120102, ICN Biomedicals, Costa Mesa, California). Dove fecal samples were analyzed in 16 assays, with each assay including all the samples from an individual bird. We followed the ICN protocol for the $\mathrm{I}^{125}$ corticosterone RIA, except that we halved the volume of all reagents (Wasser et al. 2000). We conducted a standard assay validation including assessment of parallelism, recovery of exogenous analyte, intra- and interassay precision, and assay sensitivity (Jeffcoate 1981, Grotjan and Keel 1996, O'Fegan 2000) to confirm that the assay accurately and precisely measured glucocorticoid metabolites in Mourning Dove feces. We conducted parallelism and recovery of exogenous corticosterone validation assays on two pooled fecal extract samples (low and high; each pool consisted of feces from five individuals). Parallelism ensures the assay maintains linearity under dilution, and recovery of exogenous corticosterone verifies accurate measurement throughout the working range of the assay (Jeffcoate 1981). We selected dove fecal samples and analyzed them in each assay; interassay variation was calculated from these three samples. Intra-assay variation was calculated by averaging the CVs of replicate tubes from 20 randomly chosen samples.

\section{STATISTICAL ANALYSES}

Tests for equal slopes (parallelism) were used to determine if log-transformed curves of serially diluted low and high pool extracts from Mourning Dove feces were parallel to log-transformed corticosterone standard curves (Neter et al. 1990). We used SAS (SAS Institute 1985) to perform all statistical analyses and considered test results significant for $P<0.05$. Means are presented $\pm \mathrm{SE}$.

\section{RESULTS}

\section{RADIOIMMUNOASSAY VALIDATION}

We successfully used the ICN corticosterone $\mathrm{I}^{125}$ RIA to quantify fecal glucocorticoid metabolites in Mourning Dove feces. Serial dilutions (1:2 up to 1:200) of low and high pool fecal extracts yielded displacement curves that were parallel to the standard corticosterone curve (Fig. 1). Based on the results of the serial dilutions, all fecal sample extracts were diluted with steroid dilutent to $1: 4$ or $1: 8$ prior to assay. Mean recovery of added exogenous corticosterone (range $0.5-2.5 \mathrm{ng} \mathrm{mL}^{-1}$; levels chosen to correspond with expected fecal glucocorticoid levels from actual samples) added to low and high pool fecal extracts was $92 \% \pm 2.1 \%(n=12)$. Acceptable recovery of exogenous analyte (within 90-110\%) and demonstration of parallelism suggests no sample matrix effects (Jeffcoate 1981, Grotjan and Keel 1996, O'Fegan 2000). The manufacturer's reported cross-reactivity of ICN corticosterone antisera was $100 \%$ with corticosterone and $<1 \%$ for other steroids. Assay sensitivity was $2.5 \mathrm{ng} \mathrm{g}^{-1}$. Interassay variation for 16 assays was $8.5 \%$ and average intraassay variation was $1.4 \%$. 


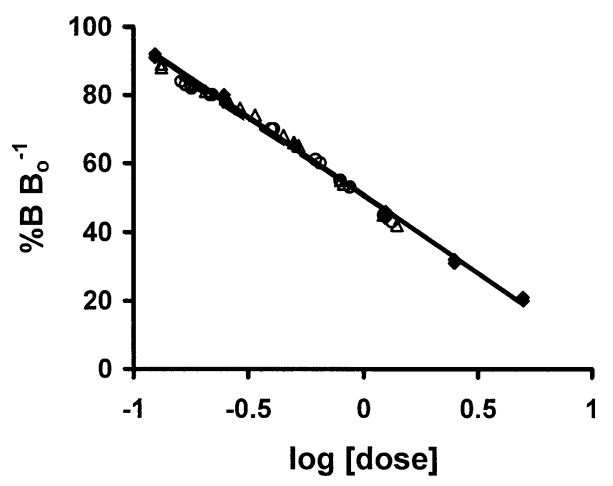

FIGURE 1. Parallelism of fecal glucocorticoid extracts for wild Mourning Doves in captivity. Curves of percent binding of $\mathrm{I}^{125}$ tracer $\left(\% \mathrm{~B} \mathrm{~B}_{\mathrm{o}}{ }^{-1}\right)$ versus serially diluted (log-transformed doses of $1: 2$ to $1: 200)$ low pool and high pool fecal extracts were parallel $(n=2$ per pool; test of equal slopes, all $P>0.3$ ) to corticosterone standard curves (log-transformed doses of 0.125 to $5.0 \mathrm{ng} \mathrm{mL}^{-1}$ ). Corticosterone standard curve points are represented by diamonds, points from serially diluted low pool fecal extracts are represented by circles, and points from serially diluted high pool fecal extracts are represented by triangles.

\section{ACTH CHALLENGE EXPERIMENTS}

We collected and assayed an average of $50.5 \pm$ 1.8 samples per bird (range $33-58, n=16$ ) during this study (total of 808 fecal samples). Mourning Doves defecated at an average rate of $0.8 \pm 0.1$ fecal samples hour ${ }^{-1}$ during the three experiments (range $0.6-1.0, n=16$ ).

Profiles of fecal glucocorticoid metabolite concentrations of Mourning Doves in the control, saline, and 1 IU per kg body mass ACTH treatment groups were similar (Fig. 2, 3). There was a pronounced rise in fecal glucocorticoid metabolite excretion, however, from all four birds (two males and two females) that received a 50 IU per kg body mass ACTH injection (Fig. 4). The ACTH-induced peak in immunoreactive fecal glucocorticoid metabolites (48-95 $\mathrm{ng} \mathrm{g}^{-1}$ ) occurred 2-4 hr after the ACTH injection (Fig. 4). Fecal glucocorticoid metabolite concentrations returned to pretreatment concentrations (12-40 $\mathrm{ng} \mathrm{\textrm {g } ^ { - 1 }}$ ) approximately 5-6 hr after ACTH injection (Fig. 4) and remained relatively stable thereafter. In contrast, fecal glucocorticoid levels remained low and did not increase during

\section{Saline}
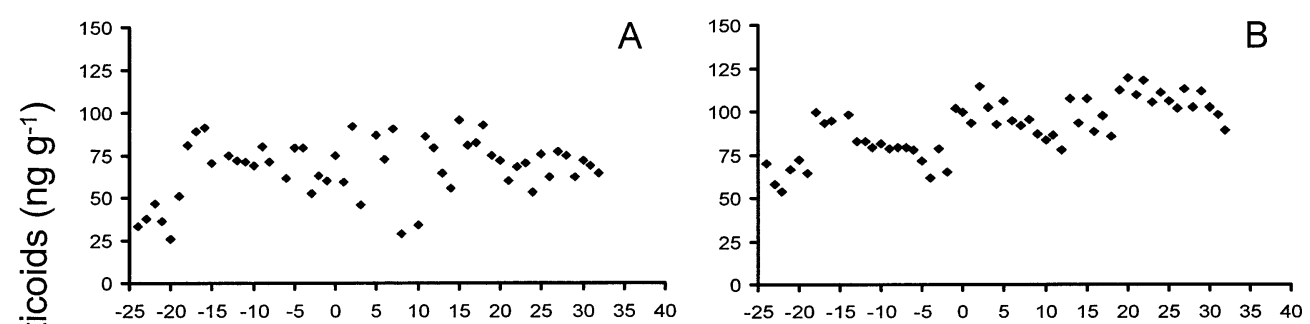

1 IU ACTH per kg body mass
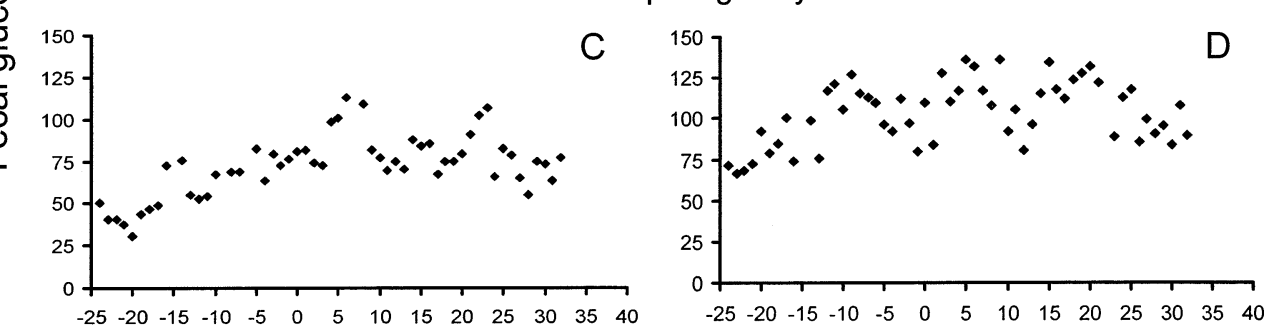

\section{Hours}

FIGURE 2. Fecal glucocorticoid metabolite $\left(\mathrm{ng} \mathrm{g}^{-1}\right)$ profiles of four after-hatch-year Mourning Doves (2 males, 2 females) during adrenocorticotropin (ACTH) challenges in winter of 2001. One female (A) and one male (B) received saline injections and one female (C) and one male (D) received a total dose of ACTH at 1 IU per $\mathrm{kg}$ body mass. Time 0 corresponds to 08:00 on day 2, the time the birds received the initial injection of saline ( $0.9 \%$ sodium chloride) or $0.5 \mathrm{IU}$ per kg body mass of ACTH. The second injection was given 30 min later. 


\section{Control (no injection)}

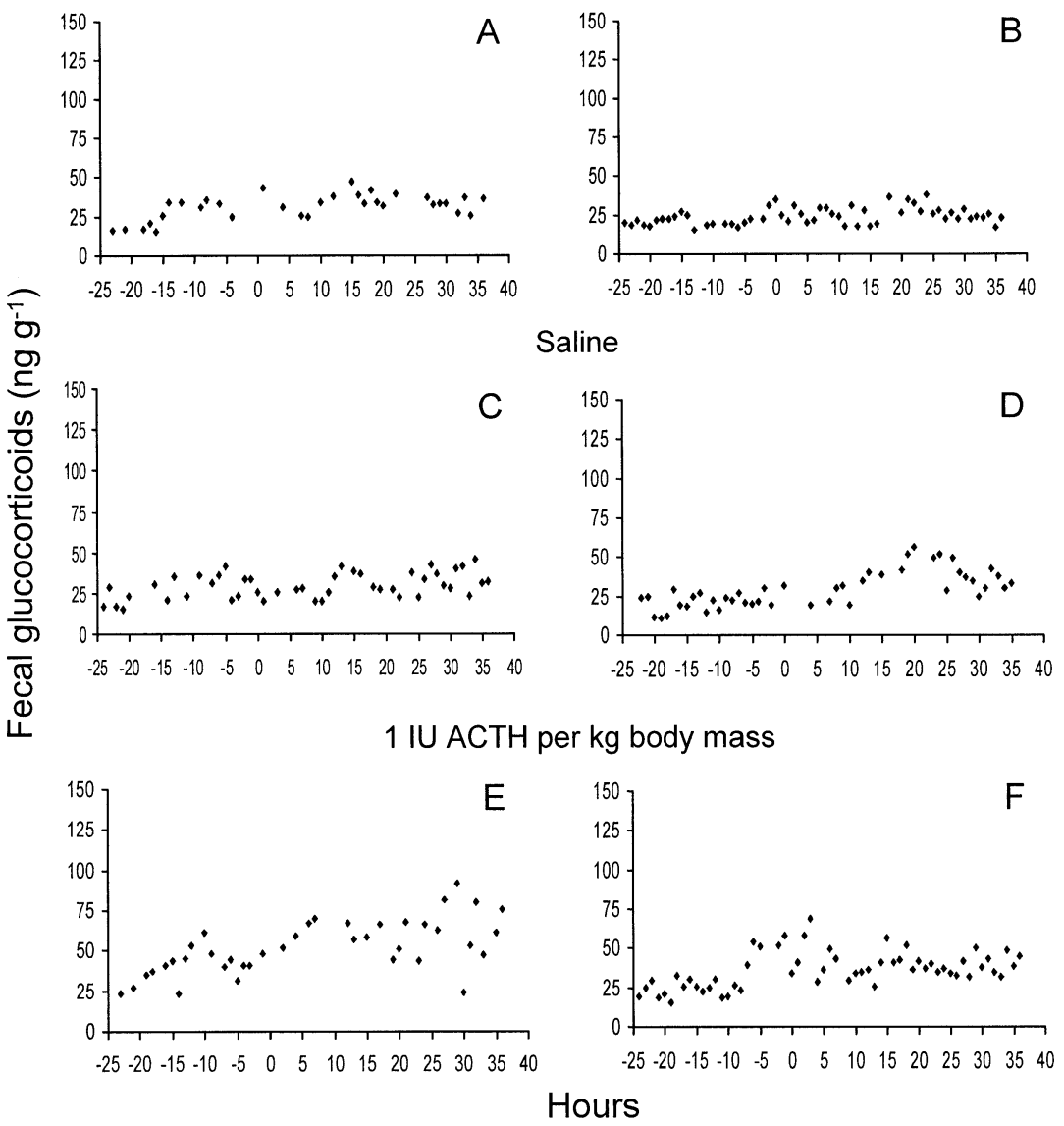

FIGURE 3. Fecal glucocorticoid metabolite $\left(\mathrm{ng} \mathrm{g}^{-1}\right)$ profiles of six after-hatch-year Mourning Doves (4 males, 2 females) during adrenocorticotropin $(\mathrm{ACTH})$ challenges in summer of 2001. Two male doves (A and B) were in the control group, one female (C) and one male (D) received saline injections, and one female (E) and one male $(\mathrm{F})$ received a total dose of $\mathrm{ACTH}$ at $1 \mathrm{IU}$ per kg body mass. Time 0 corresponds to 08:00 on day 2, the time the birds received the initial injection of saline $(0.9 \%$ sodium chloride) or 0.5 IU of ACTH per $\mathrm{kg}$ body mass. The second injection was given 30 min later.

the corresponding treatment time in the two control birds (Fig. 4).

Overall, fecal glucocorticoid metabolite concentrations were similar for males and females within treatment groups and experiments; however, variation among seasons, length of time in captivity, and individual birds was evident. Fecal glucocorticoid metabolite levels varied among experiments conducted during winter, summer, and fall. Baseline glucocorticoid metabolite levels were highest and most variable in winter experiments when the birds were in captivity for less than 3 months (range 24-138 ng $\mathrm{g}^{-1}$ ), intermediate in summer (range 16-92 ng $\mathrm{g}^{-1}$ ), and lowest in fall, when the birds had been in captivity for 5 months (range 12-40 $\mathrm{ng} \mathrm{g}^{-1}$; Fig. 2-4).

\section{DISCUSSION}

We detected elevations in fecal glucocorticoid metabolites following injection of ACTH at 50 IU per kg body mass, indicating we can reliably detect and monitor changes in adrenocortical activity in Mourning Doves using fecal glucocorticoid metabolite analysis. The performance characteristics (parallelism, recovery of exogenous corticosterone, intra- and interassay precision, assay sensitivity) of this assay verify that 
Control (no injection)
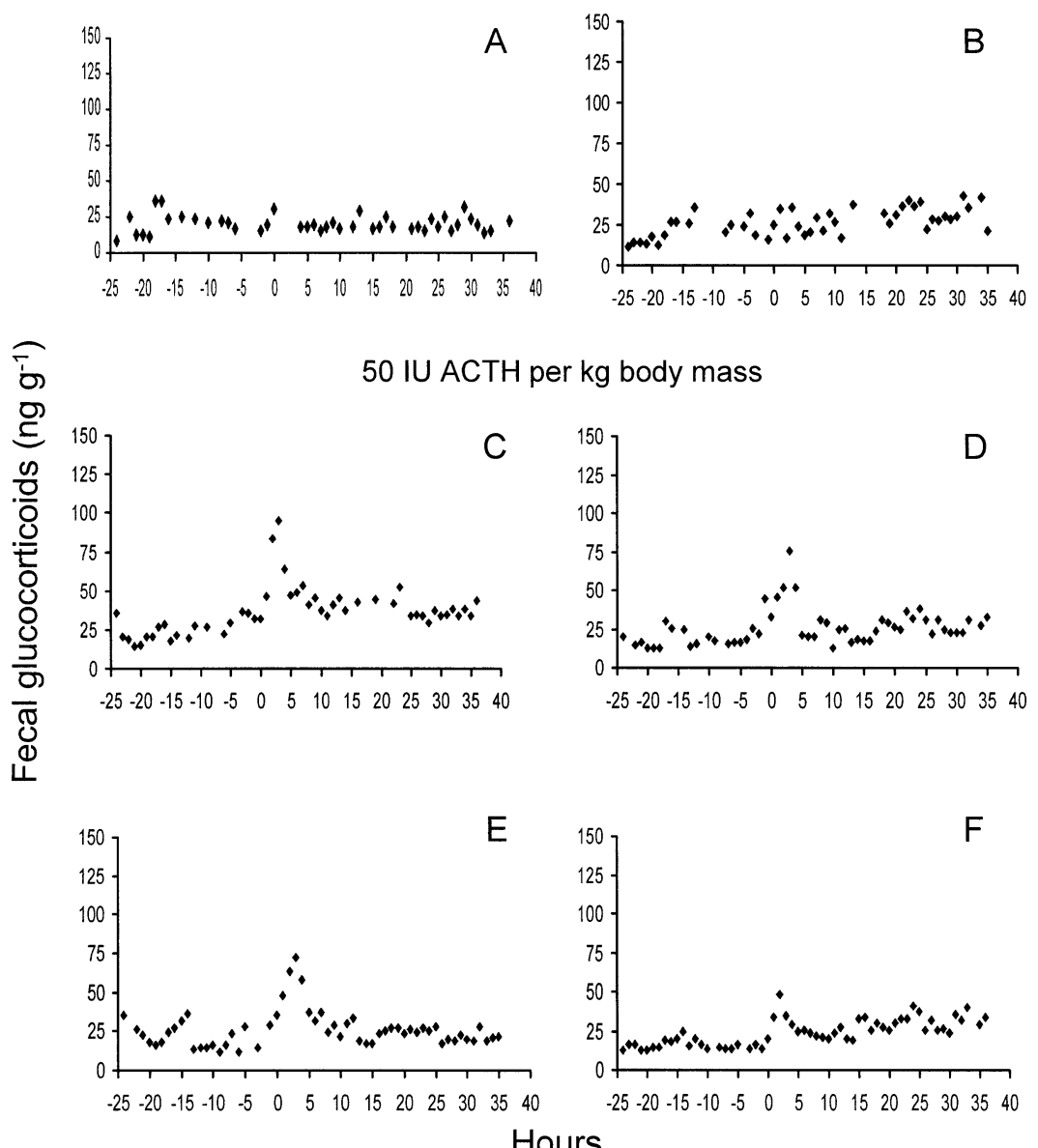

Hours

FIGURE 4. Fecal glucocorticoid metabolite $\left(\mathrm{ng} \mathrm{g}^{-1}\right)$ profiles of six after-hatch-year Mourning Doves (3 males, 3 females) during adrenocorticotropin (ACTH) challenges in fall of 2001. One female (A) and one male (B) were in the control group and two females $(C$ and $D)$ and two males (E and F) received a single dose of $A C T H$ at $50 \mathrm{IU}$ per $\mathrm{kg}$ body mass. Time 0 corresponds to 08:00 on day 2 , the time the birds received the ACTH injection.

it is accurate, precise, linear under dilution, and appropriately sensitive. To our knowledge, this study is the first to demonstrate this fecal glucocorticoid metabolite assay is useful for stress assessment in small birds $(<200 \mathrm{~g})$. Our findings are corroborated by other studies that suggest the physiological stress response of birds can be monitored using fecal glucocorticoid metabolite assays (Wasser et al. 1997, Frigerio et al. 2001, Ludders et al. 2001). Although excretion lag times (time difference between the stressful event and when fecal glucocorticoid metabolite levels are elevated) vary among species, the general patterns we observed with Mourning Doves are similar to those reported in the literature for other birds. In a female Northern Spotted Owl, fecal glucocorticoids increased within $2 \mathrm{hr}$ after ACTH injection, with maximal excretion of fecal glucocorticoid metabolites occurring $12 \mathrm{hr}$ after injection of ACTH (Wasser et al. 1997). Similarly, fecal glucocorticoid levels increased in response to ACTH administration approximately 2-3 hr after injection in Florida Sandhill Cranes (Ludders et al. 2001).

The ICN corticosterone antibody we used is effective for quantifying fecal glucocorticoid 
metabolites in other avian species (Northern Spotted Owls, Wasser et al. 1997; Florida Sandhill Cranes, Ludders et al. 2001), small mammals (Harper and Austad 2000), ungulates (Wasser et al. 2000, Millspaugh et al. 2001, 2002), felids (Graham and Brown 1996, Wasser et al. 2000), canids (Creel et al. 1997), and numerous other wildlife species (Goymann et al. 1999, Wasser et al. 2000, Foley et al. 2001). Wasser et al. (2000) compared several cortisol and corticosterone antibodies and concluded that the ICN corticosterone antibody was preferable for a diversity of species because it most reliably measured glucocorticoid metabolites in feces.

We did not detect an increase in fecal glucocorticoid metabolites following injections of saline or ACTH at a total dose of $1 \mathrm{IU}$ per $\mathrm{kg}$ body mass. Similarly, Ludders et al. (2001) did not detect an increase in serum or fecal corticosterone levels following saline injection in Florida Sandhill Cranes. Injection of Ringer's solution did not increase plasma corticosterone in Rock Doves (Columba livia; Romero and Wingfield 2001) or Gambel's White-crowned Sparrows (Zonotrichia leucophrys gambelii; Romero and Wingfield 1999). We suspect the administration of ACTH at $1 \mathrm{IU}$ per kg body mass was insufficient to cause an increase in corticosterone secretion from the adrenal glands into the bloodstream. Although a dosage of 1 IU per $\mathrm{kg}$ body mass has been effective in large mammals (Wasser et al. 2000, Millspaugh et al. 2002) and a dose of 5 IU per kg body mass was effective in Sandhill Cranes, it appears this level is not biologically important to Mourning Doves. Smaller animals, such as Mourning Doves, may naturally have higher circulating levels of endogenous ACTH, perhaps due to higher clearance rates of circulating hormones resulting from their high mass-specific metabolic rate (Mirarchi 1993b). Romero and Wingfield (1999) reported that a minimum dose of $20 \mathrm{IU}$ ACTH per kg body mass was necessary to significantly elevate plasma corticosterone in White-crowned Sparrows. Consequently, during experimentation considerably higher dosages of exogenous ACTH may be required to elicit a stress response in smaller birds (e.g., Mourning Dove) compared to larger species (e.g., Sandhill Crane).

Seasonal and life-history stage (e.g., molt) differences in basal corticosterone levels and responsiveness to stress-inducing procedures (e.g., capture stress protocol) have been documented for numerous birds, including captive and freeranging White-crowned Sparrows (Astheimer et al. 1994, Romero et al. 1997, Romero and Wingfield 1999), captive European Starlings (Sturnus vulgaris; Romero and Remage-Healey 2000), free-ranging Common Redpolls (Carduelis flammea; Wingfield et al. 1994, Romero et al. 1998a), and free-living and captive Lapland Longspurs (Calcarius lapponicus; Romero et al. 1998b). Wild birds placed in captivity typically have intermediate corticosterone levels compared to free-ranging individuals of the same species (Wingfield et al. 1982, Marra et al. 1995, Romero and Wingfield 1999). However, as the length of captivity increases, basal corticosterone levels decrease as the birds acclimate to captivity (Wingfield et al. 1982). Studies of wild White-crowned Sparrows and White-throated Sparrows (Zonotrichia albicollis) brought into captivity and housed in outdoor aviaries suggest 35 days is insufficient for these birds to acclimate to captive conditions (Marra et al. 1995, Romero and Wingfield 1999). In our study, Mourning Doves that were in captivity for 2-3 months during winter had fecal glucocorticoid metabolite levels that were 2-3 times higher than levels found during summer and fall in Mourning Doves that had been in captivity for more than 4 months. Our observed variation in overall fecal glucocorticoid levels may be due to seasonal variation in corticosterone levels, differing lengths of time in captivity, or a combination of these two factors. Further investigation is necessary to elucidate whether season and length of time in captivity are important factors that influenced fecal glucocorticoid metabolite levels in Mourning Doves in our study.

Sporadic elevations and variability in fecal glucocorticoid levels were evident in the profiles of Mourning Dove fecal glucocorticoid metabolites. Changes in weather (e.g., gusting winds), differential responses to sample collection (e.g., flashlight at night), or other events may have triggered short-term changes in fecal glucocorticoid levels, although the cause of such changes in adrenocortical activity is unknown. Fecal samples in this study consisted of both feces and uric acid. Studies in other species using radiolabeled steroids demonstrate that hormone metabolites are excreted in differing amounts in the urine and feces (Schwartz et al. 1992, TeskeyGerstl et al. 2000, Wasser et al. 2000). Thus, if 
the proportion of urine or feces varied among individual Mourning Dove fecal samples, the amount of immunoreactive fecal glucocorticoid metabolites could vary as well, increasing sample-to-sample variability (Ludders et al. 1991).

In summary, we validated a fecal glucocorticoid metabolite assay procedure that is capable of quantifying glucocorticoid metabolites in Mourning Dove feces. Noninvasive fecal glucocorticoid monitoring, used in combination with demographic information (e.g., reproductive indices), may provide an effective tool for examining the effects of various naturally occurring and human-induced stressors on Mourning Doves. Future research is needed to determine how confounding factors, such as season, length of time in captivity, daily rhythms, and effects of capture and handling, may influence basal and stress-induced fecal glucocorticoid metabolite levels in Mourning Doves.

\section{ACKNOWLEDGMENTS}

Financial and logistical support for this project was provided by a University of Missouri (MU) Life Science Mission Enhancement Postdoctoral Fellowship, a MU Research Board Grant, the MU Department of Fisheries and Wildlife Sciences, and the Missouri Department of Conservation (Federal Aid in Wildlife Restoration Project W-13-R), and the 2001 Webless Migratory Game Bird Research Program (US Fish and Wildlife Service and the USGS Biological Resources Division). Fecal glucocorticoid assays were conducted in the Wildlife Stress Physiology Laboratory in the MU Department of Fisheries and Wildlife Sciences. We thank C. Rittenhouse, R. Woeck, S. Kistner, and B. Compton for their assistance in collecting fecal samples and sample processing in the laboratory. Three anonymous reviewers provided insightful comments that improved the manuscript. This research was approved by the University of Missouri Animal Care and Use Committee (Protocol \#3581).

\section{LITERATURE CITED}

Asthemier, L. B., W. A. Buttemer, And J. C. WingFIELD. 1994. Gender and seasonal differences in the adrenocortical response to ACTH challenge in an arctic passerine, Zonotrichia leucophrys gambelii. General and Comparative Endocrinology 94 : 33-43.

Bahr, N. I., R. Palme, U. Möhle, J. K. Hodges, And M. Heistermann. 2000. Comparative aspects of the metabolism of cortisol in three individual nonhuman primates. General and Comparative Endocrinology 117:427-438.

BRAY, M. M. 1993. Effect of ACTH and glucocorticoids on lipid metabolism in the Japanese Quail, Coturnix coturnix japonica. Comparative and Biochemical Physiology 105A:689-696.
Clipsham, R. C. 1991. Restraint, sample collection and surgical preparation in the avian patient, p. 331340. In Proceedings of the annual conference of the association of avian veterinarians. Association of Avian Veterinarians, New York.

Creel, S., N. M. Creel, and S. L. Monfort. 1997. Radiocollaring and stress hormones in African wild dogs. Conservation Biology 11:544-548.

Dunlap, K. D., AND J. J. Schall. 1985. Hormonal alterations and reproductive inhibition in male fence lizards (Sceloporus occidentalis) infected with the malarial parasite Plasmodium mexicanum. Physiological Zoology 68:608-621.

Frigerio, D., E. Möstl, AND K. Kotrschal. 2001. Excreted metabolites of gonadal steroid hormones and corticosterone in Greylag Geese (Anser anser) from hatching to fledging. General and Comparative Endocrinology 124:246-255.

Foley, C. A. H., S. Papageorge, and S. K. Wasser. 2001. Noninvasive stress and reproductive measures of social and ecological pressures in freeranging African elephants. Conservation Biology 15:1134-1142.

Goymann, W., E. Möstl, T. Van't Hof, M. L. East, AND H. Hofer. 1999. Noninvasive fecal monitoring of glucocorticoids in spotted hyenas, Crocuta crocuta. General and Comparative Endocrinology 114:340-348.

Graham, L. H., AND J. L. Brown. 1996. Cortisol metabolism in the domestic cat and implications for non-invasive monitoring of adrenocortical function in endangered felids. Zoo Biology 15:71-82.

Grotjan, H. E., AND B. A. KeEl. 1996. Data interpretation and quality control, p. 51-93. In E. P. Diamandis and T. K. Christopoulos [EDS.], Immunoassay. Academic Press, New York.

Hamilton, G. D., And H. P. Weeks JR. 1985. Cortisol and aldosterone comparisons of cottontail rabbits collected by shooting, trapping, and falconry. Journal of Wildlife Diseases 31:40-42.

Harper, J. M., and S. N. Austad. 2000. Fecal glucocorticoids: a noninvasive method of measuring adrenal activity in wild and captive rodents. Physiological and Biochemical Zoology 73:12-22.

Harvey, S., J. G. Phillips, A. Rees, And T. R. Hall. 1984. Stress and adrenal function. Journal of Experimental Zoology 232:633-645.

Holberton, R. L., J. D. PARrish, AND J. C. Wingfield. 1996. Modulation of the adrenocortical stress response in Neotropical migrants during autumn migration. Auk 113:558-564.

Holmes, W. N., AND J. G. PhILliPs. 1976. The adrenal cortex of birds, p. 293-420. In I. Chester-Jones and I. Henderson [EDS.], General and comparative endocrinology of the adrenal cortex. Academic Press, New York.

JefFCOATE, S. L. 1981. Efficiency and effectiveness in the endocrinology laboratory. Academic Press, New York.

Le Maho, Y., H. Karmann, D. Briot, and Y. HanDRICH. 1992. Stress in birds due to routine han- 
dling and a technique to avoid it. American Journal of Physiology 263:R775-R781.

Ludders, J. W., J. A. Langenberg, N. M. Czekala, AND H. N. ERB. 2001. Fecal corticosterone reflects serum corticosterone in Florida Sandhill Cranes. Journal of Wildlife Diseases 37:646-652.

Marra, P. P., K. T. Lampe, and B. L. Tedford. 1995. Plasma corticosterone levels in two species of $\mathrm{Zo}$ notrichia sparrows under captive and free-ranging conditions. Wilson Bulletin 107:296-305.

Millspaugh, J. J., B. E. Washburn, M. A. Milanick, J. Beringer, L. P. Hansen, and T. M. Meyer. 2002. Noninvasive techniques for stress assessment in white-tailed deer. Wildlife Society Bulletin 30:899-907.

Millspaugh, J. J., R. J. Woods, K. E. Hunt, K. J. Raedeke, G. C. Brundige, B. E. Washburn, and S. K. WASSER. 2001. Fecal glucocorticoid assays and the physiological stress response of elk. Wildlife Society Bulletin 29:899-907.

Mirarchi, R. E. 1993a. Care and propagation of captive Mourning Doves, p. 409-428. In T. S. Baskett, M. W. Sayre, R. E. Tomlinson, and R. E. Mirarchi [EDS.], Ecology and management of the Mourning Dove. Stackpole Books, Harrisburg, PA.

MirARCHI, R. E. 1993b. Energetics, metabolism, and reproductive physiology, p. 143-160. In T. S. Baskett, M. W. Sayre, R. E. Tomlinson, and R. E. Mirarchi [EDS.], Ecology and management of the Mourning Dove. Stackpole Books, Harrisburg, PA.

Neter, J., W. Wasserman, And M. H. Kutner. 1990. Applied linear statistical models. 3rd ed. Irwin Press, Boston.

O'Fegan, P. O. 2000. Validation, p. 211-238. In J. P. Gosling [ED.], Immunoassays. Oxford University Press, New York.

Reeves, H. M., A. D. Geis, And F. C. Kniffin. 1968. Mourning Dove capture and banding. U.S. Fish and Wildlife Service Special Scientific ReportWildlife 117, Washington, DC.

Romero, L. M., M. RAMENOFSKY, AND J. C. WiNGFIELD. 1997. Season and migration alters the corticosterone response to capture and handling in an arctic migrant, the White-crowned Sparrow (Zonotrichia leucophrys gambelii). Comparative and Physiological Biochemistry 116C:171-177.

Romero, L. M., And L. Remage-Healey. 2000. Daily and seasonal variation in response to stress in captive Starlings (Sturnus vulgaris): corticosterone. General and Comparative Endocrinology 119:5259.

Romero, L. M., K. K. Soma, and J. C. Wingfield. 1998a. The hypothalamus and adrenal regulate modulation of corticosterone release in Redpolls (Carduelis flammea-an arctic-breeding song bird). General and Comparative Endocrinology 109:347-355.

Romero, L. M., K. K. Soma, And J. C. Wingfield. 1998b. Hypothalamic-pituitary-adrenal axis changes allow seasonal modulation of corticoste- rone in a bird. American Journal of Physiology 274:R1338-R1344.

Romero, L. M., AND J. C. WingField. 1999. Alterations in hypothalamic-pituitary-adrenal function associated with captivity in Gambel's Whitecrowned Sparrows (Zonotrichia leucophrys gambelii). Comparative Biochemistry and Physiology B 122:13-20.

Romero, L. M., AND J. C. WingField. 2001. Regulation of the hypothalamic-pituitary-adrenal axis in free-living pigeons. Journal of Comparative Physiology B 171:231-235.

SAS InSTITUTE INC. 1985. SAS user's guide: statistics, version 5. SAS Institute Inc., Cary, NC.

Schulz, J. H., A. J. Bermudez, J. L. Tomlinson, J. D. FIRMAN, AND Z. HE. 2001. Comparison of radiotransmitter attachment techniques using captive Mourning Doves. Wildlife Society Bulletin 29: 771-782.

Schwartz, J. R., T. S. Gross, D. A. Stark, T. ThanNISH, AND M. M. BECK. 1992. Analysis of radiolabeled steroid metabolism and excretion in Cattle Egrets (Ardeola ibis). Biology of Reproduction 46(Supp. 1):96.

Schwarzenberger, F., E. Möstl, E. Bamberg, J. PamMER, AND O. SCHMEHLIK. 1991. Concentrations of progestagens and oestrogens in the faeces of pregnant Lipizzan, trotter and thoroughbred mares. Journal of Reproduction and Fertility Supplement 44:489-499.

Teskey-Gerstl, A., E. Bamberg, T. Steineck, and R. PALME. 2000. Excretion of corticosteroids in urine and feces of hares (Lepus europaeus). Journal of Comparative Physiology B 170:163-168.

Verme, L. J., AND R. V. DOEPKER. 1988. Suppression of reproduction in Upper Michigan white-tailed deer, Odocoileus virginianus, by climatic stress during the rut. Canadian Field-Naturalist 102: $550-552$.

Washburn, B. E., D. L. Morris, J. J. Millspaugh, J. FAABORG, AND J. H. Schulz. 2002. Using a commercially available radioimmunoassay to quantify corticosterone in avian plasma. Condor 104:558563.

Wasser, S. K., K. Bevis, G. King, and E. Hanson. 1997. Noninvasive physiological measures of disturbance in the Northern Spotted Owl. Conservation Biology 11:1019-1022.

Wasser, S. K., K. E. Hunt, J. L. Brown, K. Cooper, C. M. Crockett, U. Bechert, J. J. Millspaugh, S. Larson, and S. L. Monfort. 2000. A generalized fecal glucocorticoid assay for use in a diverse array of non-domestic mammalian and avian species. General and Comparative Endocrinology 120:260-275.

WingField, J. C. 1988. Changes in reproductive function of free-living birds in direct response to environmental perturbations, p. 121-148. In J. H. Stetson [ED.], Processing of environmental information in vertebrates. Springer-Verlag, Berlin. 
Wingfield, J. C., C. Breuner, and J. Jacobs. 1997. Corticosterone and behavioral responses to unpredictable events, p. 267-278. In S. Harvey and R. J. Etches [EDS.], Perspectives in avian endocrinology. Journal of Endocrinology Ltd., Bristol, UK.

Wingfield, J. C., P. Deviche, S. Sharbough, L. B. Astheimer, R. Holberton, R. Suydam, and K. HunT. 1994. Seasonal changes in the adrenocortical responses to stress in Redpolls, Acanthis flammea, in Alaska. Journal of Experimental Zoology 270:372-380.

Wingfield, J. C., J. P. Smith, And D. S. FARner. 1982. Endocrine responses of White-crowned Sparrows to environmental stress. Condor 84:399-409.

Wingfield, J. C., C. M. Vleck, And M. C. Moore. 1992. Seasonal changes in the adrenocortical response to stress in birds of the Sonoran Desert. Journal of Experimental Zoology 264:419-428. 